\title{
想定建物の冬期施工の増工費の工事条件による変動 VARIATION OF ADDITIONAL COSTS OF WINTER CONSTRUCTION OF ASSUMED BUILDINGS OWING TO THE DIFFERENCE OF CONSTRUCTION CONDITIONS
}

\author{
中村裕 史* \\ Hiroshi NAKAMURA
}

\begin{abstract}
Additional costs for winter cares are required in building construction of cold seasonsin Hokkaido. The amount of additional costs vary when the conditions such as construction time or region are different..In this paper, several buildings are assumed and winter additional costs of the buildings are estimated under various construction conditions. According to the results of estimation, variation of additional costs is clarified and methods of costs reduction are suggested. Moreover, the rates of additional costs to building costs are roughly calculated and the rates in case of year-round construction are also mentioned.
\end{abstract}

Keywords : assumed buildings, winter construction, additional costs, construction conditions, variation of additional costs 想定建物、冬期施工、増工費、工事条件、増工費の変動

\section{1.はじめに}

北海道において、冬期間に建築工事を行う冬期施工には、冬期養 生のための割増し工事費である増工費が必要となる。この増工費 は、建物が同じであっても、工事条件などの違いによって大きく変 動する。

本報では規模の異なる数種の建物を想定し、施工時期、建設地、 あるいは週休などの工事条件などが変る場合の増工費を算定し、増 工費がごのように変動するかを明らかにする。また、建築工事費に 対する増工費の比率である増工費率がどの程度になるかを概算し、 通年施工の前提となる工事平準化の場合の増工費率について触れる。

\section{2. 想定建物と工事条件}

\section{1 想定建物}

基本的な想定建物は表 1 に示す鉄筋コンクリート造の 4 種 （No.1 No.4）である。これらは「冬期建築工事の増工費の算定 基準」1にある基準階面積の区分に基づいて想定した。

想定建物No.3については建物の平面形状が異なる場合（No.31 32）や、階数などが異なる場合（No.33，34）も想定し、それぞれ の場合の増工費の違いを明らかにした。

算定基準に基づく各想定建物の標準工期の概要を図 1 に示す。

\section{2 工事条件}

各想定建物について、增工費を算定する際の着工時期、建設地、 週休などの工事条件を表 2 のように設定した。

\section{3. 増工費の算定}

表 1 想定建物の概要（鉄筋コンクリート造） a)

\begin{tabular}{|c|c|c|c|c|c|c|c|}
\hline $\begin{array}{l}\text { 想定 } \\
\text { 建物 }\end{array}$ & $\begin{array}{l}\text { 基準階 } \\
\text { 面積 } \\
\left(\mathrm{m}^{2}\right)\end{array}$ & $\begin{array}{l}\text { 階 } \\
\text { 数 }\end{array}$ & $\begin{array}{l}\text { 延べ床 } \\
\text { 面積 } \\
\left(\mathrm{m}^{2}\right) \\
\end{array}$ & $\begin{array}{l}\text { コン仯 } \\
\text { 基礎 }\end{array}$ & $\begin{array}{l}\text { 打設量 } \\
\text { 各階 } \\
\end{array}$ & $\begin{array}{l}\text { 平面形犾 } \\
\text { 幅 } \times \text { 長さ } \\
\text { (m) (m) }\end{array}$ & $\begin{array}{c}\text { 施工日数 } \\
\text { b) } \\
\text { (日) }\end{array}$ \\
\hline to. 1 & 300 & 2 & 600 & 75 & 150 & $15 \times 20$ & 145 \\
\hline$a 2$ & 1,000 & 2 & 2,000 & 250 & 500 & $20 \times 50$ & 165 \\
\hline a 3 & 2,000 & 3 & 6,000 & 500 & 1,000 & $20 \times 100$ & 220 \\
\hline 4 & 3,000 & 4 & 12,000 & 750 & 1.500 & $20 \times 150$ & 275 \\
\hline$\sqrt{0.31^{\circ 2}}$ & 2,000 & 3 & 6,000 & 500 & 1,000 & $40 \times 50$ & 220 \\
\hline 32 & 2,000 & 3 & 6,000 & 500 & 1,000 & $10 \times 200$ & 220 \\
\hline $233^{d /}$ & 500 & 4 & 6,000 & 375 & 750 & $20 \times 75$ & 230 \\
\hline 0.34 & 3,000 & 2 & 6,000 & 750 & 1,500 & $20 \times 150$ & 225 \\
\hline
\end{tabular}

a) 各想定建物とも、基礎高 $=0.6 \mathrm{~m}$ 、各階高 $=3.7 \mathrm{~m}$ 、取付道路長さ $=0 \mathrm{~m}$ 。 階高、コンクリート打設量などは諸資料 2 '.3)を参考に設定。

b）「冬期建築工事の增工費の算定基準」"による。

c) No.31,32はNo. 3と、平面形状が異なる。

d)№. 33,34はNo. 3と、延べ床面積が同じで、階数、基準階面積、 平面形状などが異なる。

\footnotetext{
*工博(当時：北海道立寒地住宅都市研究所 特別研究員)
} 
各工事条件の下における想定建物の増工費は、「冬期建築工事の 增工費の算定基準」1により算出した。増工費算出のための単価は、 北海道住宅都市部の1995年の標準単価を参考に設定した。なお、增 工費の要因、工事内容の概説は、文末の注の増工費の構成に示す。

\section{4. 增工䫓の箇定結果と考察}

基本的な想定建物（No.1〜No.4）の増工費の算定結果を、各月 初日の着工時期別に、単位増工費（単位床面積当たりの增工費）の 形で、内訳を含めて図 2 に示す（建設地：札幌、週休：4週 6 休）。

\section{1 着工時期別の単位増工䁂}

（1）全般に単位增工費は着工時期が春先 ( 3 月〜 5月)であるほど小さ く、秋から冬（9月～1月）にかけての初冬が大きい。着工時期が 春先の場合、工期が冬期（増工費の算定時期）にかからない、ある いはかかってもその期間が短いためである。逆に着工時期が初冬の

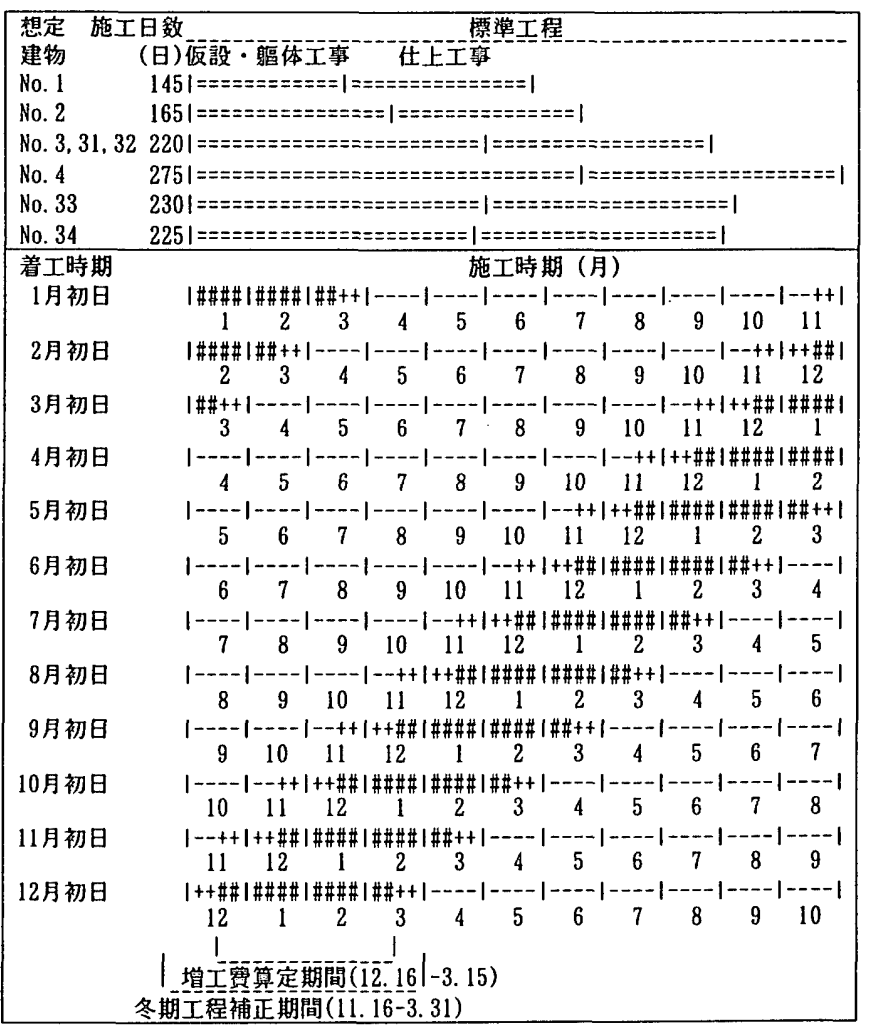

図 1 想定建物の摽準工程と施工時期の概要

表 2 想定建物の增工費算定の際の工事条件

\begin{tabular}{|c|c|c|c|c|}
\hline 想定 & & I 事 条 件 & & 備考（算定結果 \\
\hline 建物 & 着工時期 & 建設地 & 週休时 & 比皎事項） \\
\hline$\sqrt{1}$ & $\cdot 1 \sim 12$ 月 & •札皦(温暖、多雪) & .4 週6休 & •着工時期別 \\
\hline 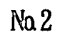 & （各月の & 。旭川(寒冷、多霓) & -4 週 2 休 & • 建物規模別 \\
\hline $\mathbb{0} 3$ & 初日） & ‘釧路(寒冷、少雪) & （札幌のみ） & •建設地別 \\
\hline $\mathrm{Na} 4$ & & 。室䕡（温暖、少雪） & & -週休別 \\
\hline $\begin{array}{l}31 \\
32\end{array}$ & 12月 & -札龔 & -4 週 6 休 & •平面形状別 \\
\hline $\begin{array}{l}\text { a.33 } \\
a 34\end{array}$ & -1〜12月 & 。札壇 & •4 週 6 休 & 。階数等別 \\
\hline
\end{tabular}

a) 4 週6 休の休日：各日曜日。增工費算定の際は1月1日を最初の 日曜とする（日曜日ごとの休日では 4 週 4 休となるが、これは標 準工期の中に 4 週 2 休分が既に組み込まれているためである)。 4 週6 休の正月休み：12月29日から1月3日までの6日間 （4週 2 休の場合は、正月休みは見込んでいない）。
場合、多くの増工費を要する躯体工事が冬期にかかり、増工費が大 きくなる (図 1 参照)。単位增工費が最大となる着工時期は建物の 規模が比較的小さい建物（No.1、No.2）では12月で、規模の大き い建物（No.3、No.4）ではこれが9月、10月へと移行している。 (2) 単位增工費の比較的大きい着工時期 ( 8 月〜 2 月)で内訳（養生囲 い費、加熱羑生費、調合変更費) を見ると、養生囲い費が最大であ
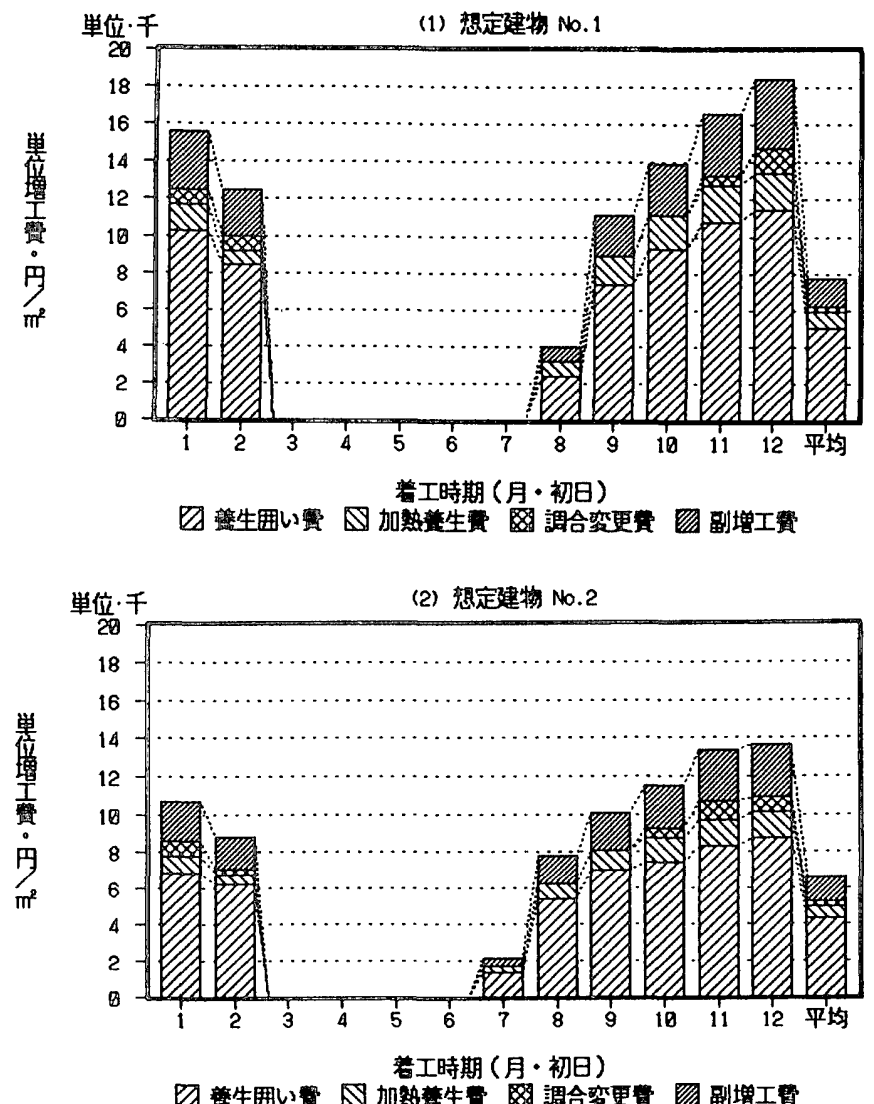

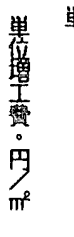
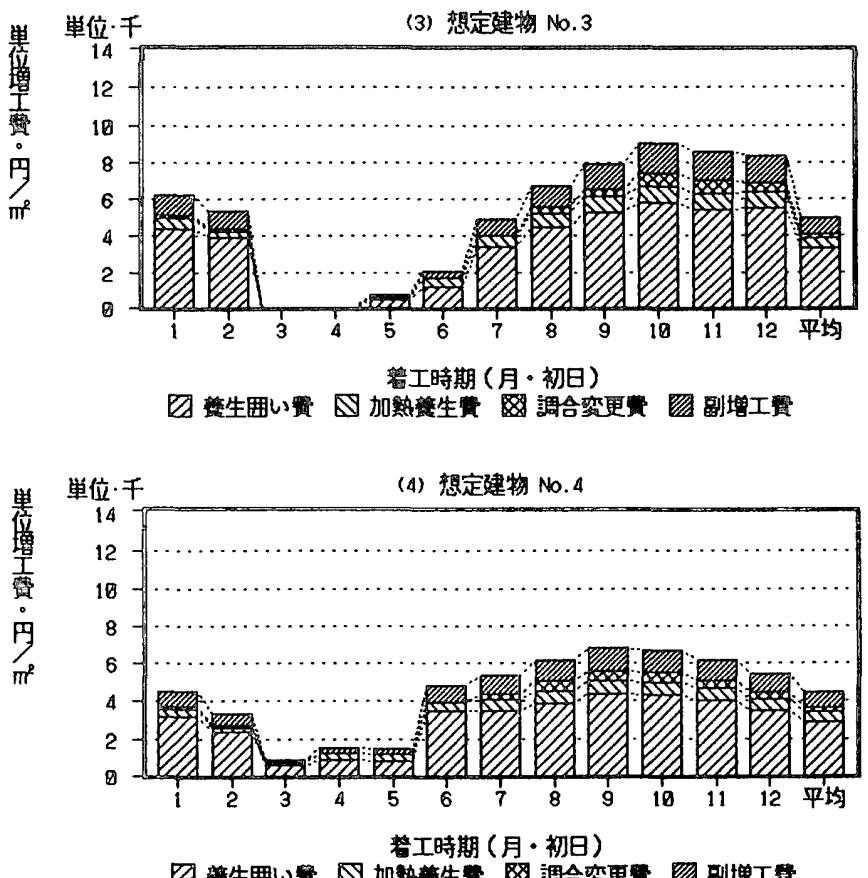

図 2 各想定建物の着工時期別の単位增工費（札幌、4 週 6 休） 
り、年平均では全体の $1 / 3$ 近くを占めている。次いで加熱養生

費、調合変更費となるが、これらは養生囲い費の半分に満たない。

\section{2 建物規模別の単位増工費}

想定建物別（No.1〜No.4）、すなわち建物の規模（延べ床面 積）別の単位増工費の比較を図 3 に示す（建設地：札幌、週休：4 週6 休)。

（1）単位増工費が比較的大きい着工時期（9月〜 2 月）で見ると、 建物規模が小さいほど単位増工費が大きくなる傾向が同える。この 傾向は年平均の単位増工費でも同じである。

想定建物No.1 1 No.4の単位增工費を比較すると、両者で最も大 きな差が出るのは着工時期が 12 月〜 2 月で、No.1はNo.4の 3 倍 以上にもなっている。年平均でもNo.1はNo.4の73\%増と大きい。

（2）建物規模別で単位増工費にこのような大きな差が生ずるのは次 の理由による。

一つ目は、規模の小さい建物は施工日数（全工期）が短いため、 規模の大きい建物に比べて、施工日数に占める增工費算定期間（以 下、算定期間）が相対的に長くなることにより、単位增工費も大き くなる。施工日数に対する算定期間（90日）の割合は、例えば No.1は62\%（90/145）で、No.4の33\%（90/275）の2 倍近く になる（図 1参照）。

二つ目は、規模の小さい建物は、各階ごとの施工日数が短いた め、算定期間中の施工階数（箇所）が多くなる。施工階数が増えれ ば、養生囲いでは設置箇所や盛り替え回数が、また加熱養生では加 熱機の据え付け・撤去回数が増加するなど、それだけ増工費がかさ むことになる。例えば図 4 に示すように、着工時期が 12 月の場合、 算定期間における施工階数は、No.1 では基礎、躯体 1 階、躯体 2 階、屋上、内仕上 1 階の 5 籄所であるのに対し、No.4では基礎と

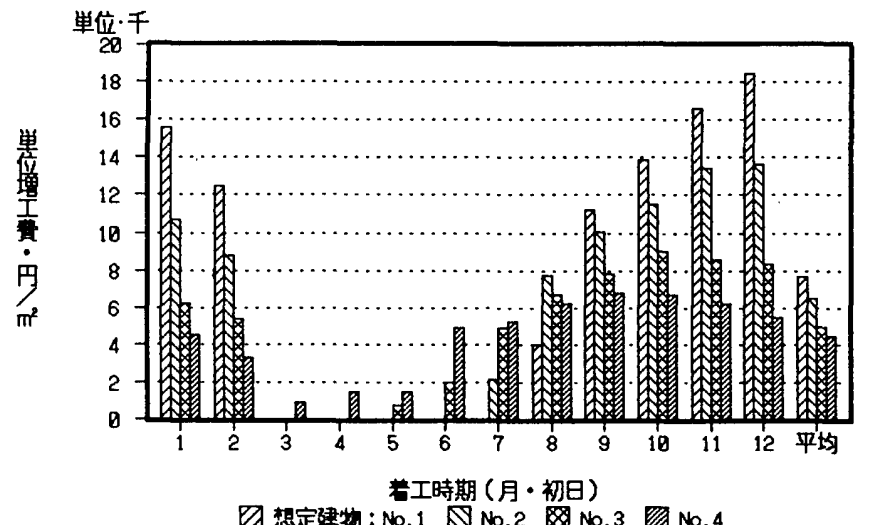

困3 建物規模別の単位增工費の比較（札幌、4 週6 休）

増工費算定期間

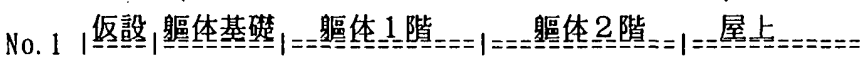
l==垈垈上皆

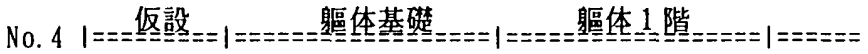

目4 想定建物No.1と№.4の增工費算定期間の施工階数 （着工時期が12月の例）
躯体 1 階の 2 箇所に過ぎない（図 4）。

\section{3 建設地別の単位増工費}

建設地別（札幌、旭川、釧路、室蘭）の単位増工費の比較を、 No.3の建物を例に着工月別に図 5 に示す（4週 6 休）。

（1）建設地によって増工費に違いが生ずるのは、表 3 に示すよう に、一つ目は加熱養生費に関わる、地区加熱補正值」が、二つ目は 副増工費（文末の [注] 参照）に関わる「副増工費率」が、それぞ れ建設地ごとに異なるためである。

（2）全般に増工費の大きさは旭川、札幌、釧路、室蘭の順である。 年平均の単位增工費で、最も小さい室蘭の值を基準にすると、旭川 が $4.2 \sim 6.3 \%$ 増、札幌が $3.4 \sim 4.2 \%$ 増、釧路が $1.5 〜 2.7 \%$ 增であ る。旭川と札幌の増工費が釧路と室蘭に比べて大きいのは、建設地 によって増工費に違いが生ずる $2 つ$ 要因のうち、「副增工費率」 の相違が大きく効いているためである。

\section{4 週休別の単位増工費}

週休別（4週 6 休、 4 週 2 休。以下それぞれ 6 休、2 休）の単位 増工費の比較を、建設地が札幌における想定建物No.3を例に、着工 月別に図 6 に示す。表 4 は各想定建物について、着工時期ごとに週 休別の単位增工費の大小の比較を示したものである。

（1）着工時期の違いによる増工費の増减の傾向は、6 休と 2 休でほ ぼ同じである。すなわち、増工費は着工時期が春先で小さく、初冬 で大きい(図 6) 。

（2）年平均の単位增工費は、いずれの想定建物も 6 休が 2 休を 10 \%前後上回っており、週休 2 日制が進むにつれて全般に増工費が大 きくなる傾向が伺える（表 4）。

（3）増工費の着工時期ごとの比較

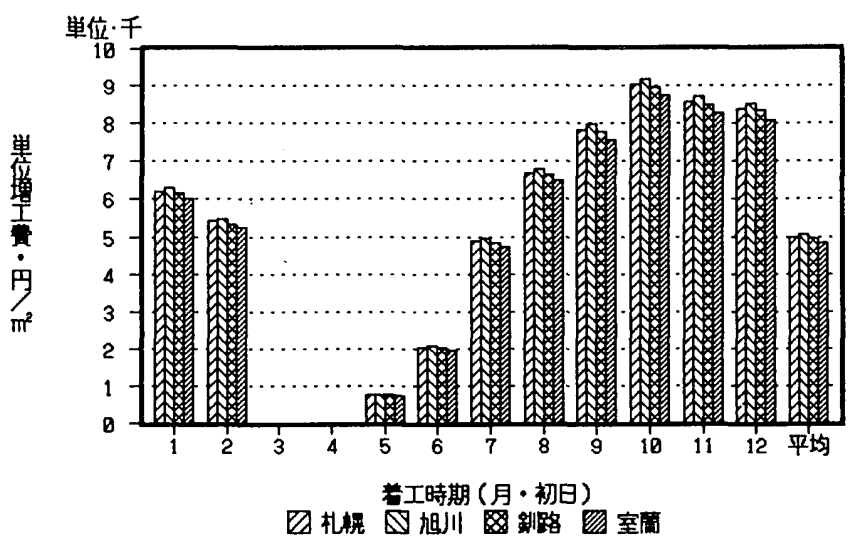

図 5 建設地別の単位增工費の比較（想定建物NNo.3、4 週6 休）

表 3 建設地別の単位增工費の比較（4 週 6 休）

\begin{tabular}{|c|c|c|c|c|c|c|c|}
\hline \multirow{3}{*}{$\begin{array}{l}\text { 建 } \\
\text { 設 } \\
\text { 地 }\end{array}$} & \multirow{3}{*}{$\begin{array}{l}\text { 地区 } \\
\text { 加熱 } \\
\text { 補正 } \\
\text { 値 }\end{array}$} & \multicolumn{2}{|c|}{ 副增工費率"1 } & \multicolumn{4}{|c|}{$\begin{array}{l}\text { 年平均単位増工費の建設地の比較 } \\
(\text { 室蘭 }=100)\end{array}$} \\
\hline & & \multirow{2}{*}{\multicolumn{2}{|c|}{$\begin{array}{l}\text { 延べ床面積 }\left(\mathrm{m}^{2}\right) \\
\langle 5,000\rangle=5,000\end{array}$}} & \multicolumn{4}{|c|}{ 想定建物（延べ床面積・ $\mathrm{m}^{2}$ ) } \\
\hline & & & & $\begin{array}{l}\text { No. } 1 \\
(600)\end{array}$ & $\begin{array}{r}\text { No. } 2 \\
(2,000)\end{array}$ & $\begin{array}{r}\text { No. } 3 \\
(6,000)\end{array}$ & $\begin{array}{r}\text { No. } 4 \\
(12,000)\end{array}$ \\
\hline 太幌 & 1.0 & 0.25 & 0.22 & 104.2 & 104.2 & 103.4 & $\overline{103.4}$ \\
\hline 且川 & 1. 1 & 5 & 0.22 & 104. 2 & 106.3 & 105.0 & 104.5 \\
\hline 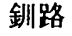 & 1.2 & 20 & 0.18 & 101.5 & 102.7 & 102.6 & 102.3 \\
\hline 室蘭 & 1.0 & 0.20 & 0.18 & 100 & 100 & 100 & 100 \\
\hline
\end{tabular}


増工費を着工時期ごとに比較すると、図 6 、表 4 に示すように、 6 休が 2 休を上回るケース（着工時期が主に 3 月〜 10月）と、逆に 下回るケース（11月～2月）が見られる。増工費にこのような違い が生ずるのは、2休に比べて、6休では休日が増えることによって 工期が相対的に延びるためである。算定期間にかかる工程（算定工 程）の違いによって、6休と 2 休の違いの理由は次のように説明で きる（表 4、図7）。

1） 6 休が 2 休を上回るケース

ア. 2 休では工程が算定期間にかからないのに対し、6 休では工期

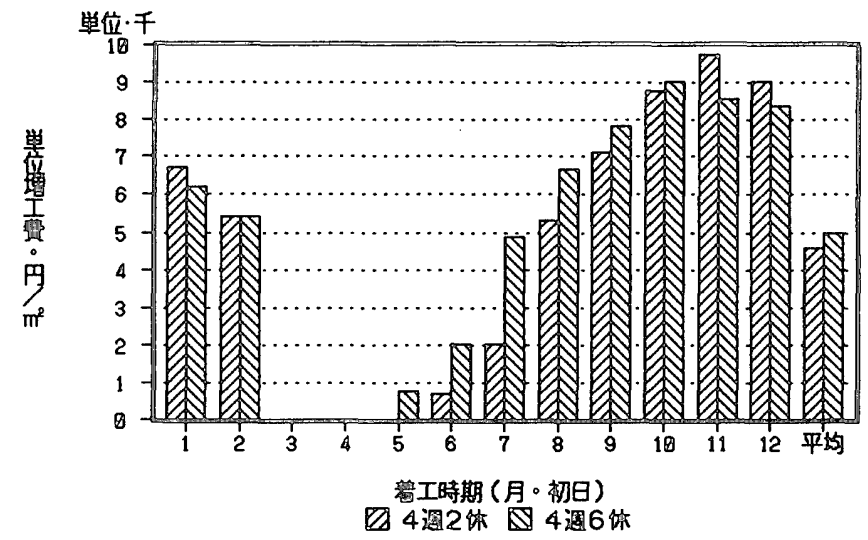

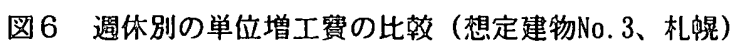

表 4 着工時期別の単位增工負の週休別の比渂（札晥）

\begin{tabular}{|c|c|c|c|c|c|c|c|c|c|c|c|c|c|}
\hline 想定 & & & & 着 & & & 時 & & 㫜 & & & & \\
\hline 建物 & 1 & 2 & 3 & 4 & 5 & 6 & 7 & 8 & 9 & 10 & 11 & 12 & 平垃 \\
\hline No. 1 & (2) & (C) & - & - & - & - & - & 㗀 & (1) & $\triangle 1$ & (2) & (a) & 1.13 \\
\hline No. 2 & (0) & () & - & - & - & - & 滑 & (III) & (4) & $\mathbb{A}$ & $\mathbb{A}$ & (0) & 1. \\
\hline No. 3 & (O) & (2) & - & - & 留 & (17) & (i) & $\mathbb{M}$ & $\mathbb{A}$ & 㐫 & (a) & (O) & 1. \\
\hline No. 4 & (2) & (0) & 四 & (III) & (iD) & $\mathbb{A}$ & $\mathbb{A}$ & $\mathbb{A}$ & $\mathbb{M}$ & (2) & (a) & (a) & 1.10 \\
\hline
\end{tabular}

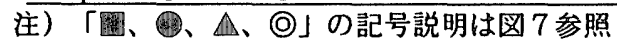

「平均」は（4週6休 $/ 4$ 週 2 休）の値

1） 6 休が 2 休を上回るケース

7. 2 休に比べ 6 休は工期が延びるため（以下同じ） 工程の後半部分が算定期間にかかる

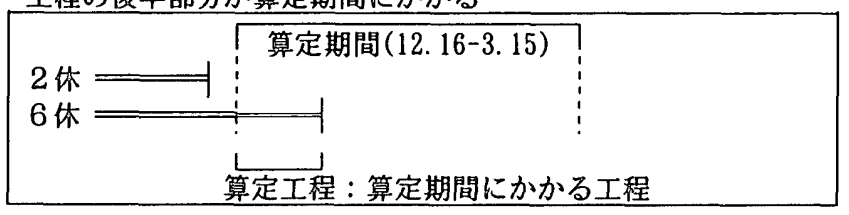

\section{1. 全体の算定工程が長くなる}

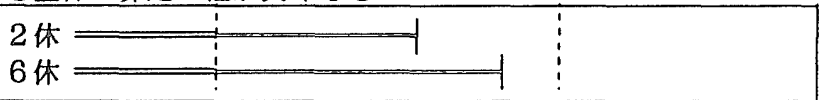

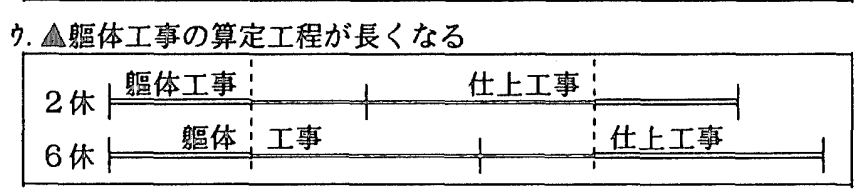

2） 6 休が 2 休を下回るケース

(算定工程が相対的に短くなる

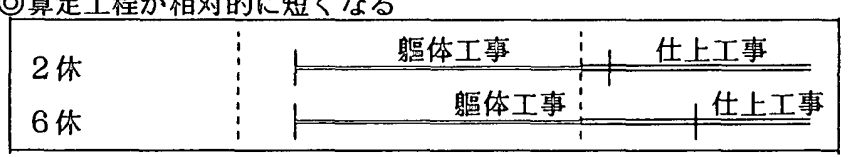

図 74 週 2 休と 4 週 6 休の增工覺の相遠の要因
が延びるため、工程の後半部分が算定期間にかかる（表 4、図 7 ア の眣）。

1. 2 休も 6 休も工程の後半部分が算定期間にかかるが、 2 休に比 べて、6休は工期が延びるため、算定工程がより長い（表 4、図 7 1の○) 。

ウ. 2 休も 6 休も工程の中間部分が算定期間にかかり、算定工程の 長さは同じである。しかし 2 休に比べ、6休は増工費がより多くか かる躯体工事の算定工程の割合が大きい（表 4、図 7ウの山）。

2） 6 休が 2 休を下回るケース

2 休も 6 休も工程の前半部分が算定期間にかかり、算定工程の長 さは同じである。しかし 2 休に比べ、工期が延びる 6 休では、全工 期に対する算定工程が相对的に短く、これに伴って增工費も小さい (表4、図7の@)。

\section{5 平面形状別の単位增工舅}

基準階面積などが同じで、建物の平面形状、すなわち幅と長さの 比が異なる想定建物（No.3、No.31、No.32）の単位增工費などの 比較を図 8、表 5 に示す（建設地：札幌）。

（1）基準階面積や延べ床面積は同じでも、外壁の短辺に対する長辺 の比が大きい建物ほど、単位増工費は大きい。この比が小さい建物 に比べ、大きい建物は、外壁の外側に $2 \mathrm{~m}$ 隔てた囲いの周囲長さ や、その内部の加熱空間が、相対的に增え、これに伴って盖生囲い 費や加熱盖生が大きくなるためである（表 5 ）。

（2）平面形状がほぼ正方形に近い建物（No.31、40m $\times 50 \mathrm{~m}$ ）を基 準に単位增工費を比べると、極端に細長い建物（No.32、10 $\mathrm{m} \times$ $200 \mathrm{~m})$ は年平均で $34 \%$ 増、単位増工費が最も大きい着工時期（10 月）で $32 \%$ 増となっている。増加率が最も高いのは 6 月着工の 100 \%增（2 倍）である。

同様に、比較的細長い建物（No.3、20m× $100 \mathrm{~m}$ ）は年平均で $9 \%$ 增、単位增工費が最も大きい着工時期（10月）で $8 \%$ 增にとどまっ

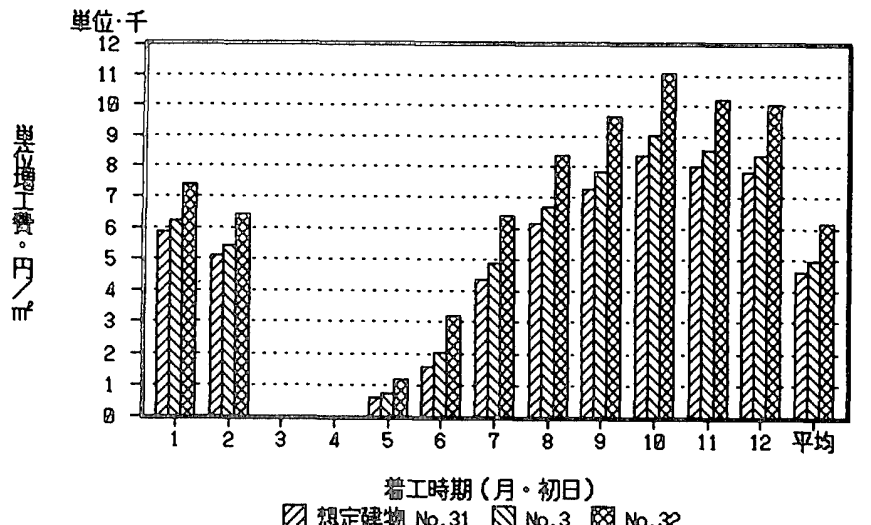

図 8 平面形状別の単位增工費の比皎（札幌）

表 5 平面形状別の単位增工費などの比皎 （基準階面稆 $=2,000 \mathrm{~m}^{2}$ 、階数 $=3$ 、延べ床面積 $=6,000 \mathrm{~m}^{3}$ 、札䖧）

\begin{tabular}{|c|c|c|c|c|c|c|c|c|}
\hline & \multirow{2}{*}{\multicolumn{2}{|c|}{$\begin{array}{ll}\text { 幅 } \times \text { 長 } & \text { 長辺 } \\
\text { (回) (回) } & \text { 短辺比 } \\
\end{array}$}} & \multirow{2}{*}{\multicolumn{2}{|c|}{$\begin{array}{l}\text { 囲い平面蛽 } \\
\left(\mathrm{m}^{2}\right) \text { 比 }\end{array}$}} & \multirow{2}{*}{\multicolumn{2}{|c|}{$\begin{array}{l}\text { 用い外周長 } \\
\text { (m) 比 }\end{array}$}} & \multicolumn{2}{|c|}{ 年平均単位增工費 } \\
\hline & & & & & & & (田 $\left./ m^{3}\right)$ & \\
\hline & & & & & & & & \\
\hline & & & & & 25 & & & \\
\hline & $a x+2$ & & & & & & & \\
\hline
\end{tabular}


ている。増加率が最も高いのは 6 月着工の $27 \%$ 増である。

（3）今回は平面形状が違っても、コンクリート打設量を同一として 増工費を算出した。平面形状に応じてコンクリート打設量を変えれ ば、形状の違いによる增工費の差は更に大きくなる。

\section{6 階数等別の単位増工費}

延べ床面積が同じで、基準階面積・階数・平面形状などの異なる 場合の単位増工費などの比較を図 9 、表 6 に示す（想定建物：

No.3、No.33、No.34、建設地：札幌）。

（1）延べ床面積が同じでも、階数等が異なると単位増工費に大きな 違いが生ずる。階数が 4 階のNo.33を基準にすると、年平均の単位 增工費は 3 階のNo.3で22\%增に、2 階のNo.34で65\%增になって いる。すなわち、基準階面樻が大きく、階数が少ないほど、単位増 工費は大きくなる。このような相違が生ずる主な理由として、次の 2つが挙げられる。

（2）一つ目は、比較した想定建物の平面形状が、階数が少ないほど 細長くなっていることによる $(4.5$ 参照)。

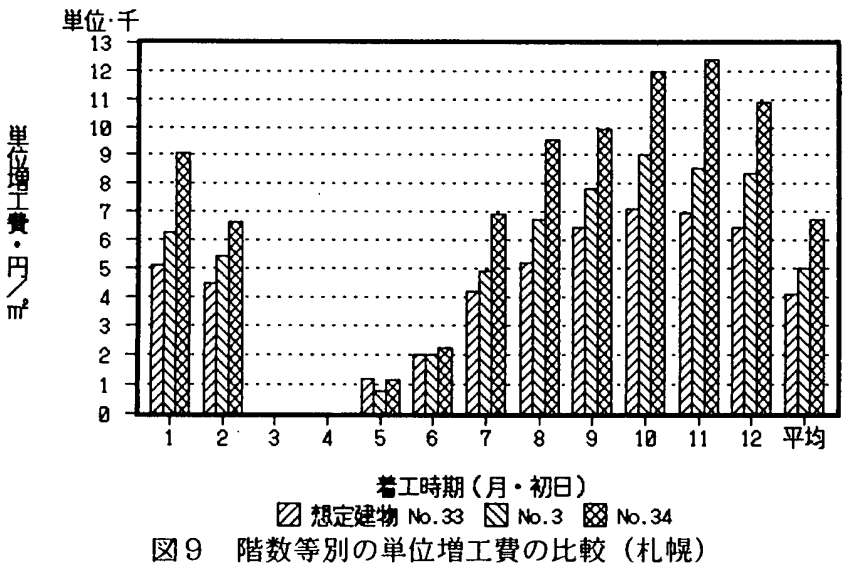

表 6 階数等別の単位增工費などの比較

\begin{tabular}{|c|c|c|c|c|c|c|}
\hline 定 & 基準階面積 & 階 & 平面形状 & 長短 & T比 & 年平均単位增工費 \\
\hline 事物 & $\left(\mathrm{m}^{3}\right)$ & 数 & $(m \times m)$ & 辺比T & & の比較 $(\mathrm{Na} 33=100)$ \\
\hline 233 & $1,500 \quad 1$ & $\overline{4}$ & $20 \times 75$ & 3.75 & 1 & 100 \\
\hline $0^{6}$ & $2.000 \quad 1.3$ & 3 & $20 \times 100$ & 5 & 1.3 & 121.9 \\
\hline Na 3 & 000 & 2 & $20 \times 150$ & 7.5 & 2 & 164.6 \\
\hline
\end{tabular}

表 7 階数等別の增工費算定階数の比較

\begin{tabular}{|c|c|c|c|c|c|c|c|c|c|c|c|c|}
\hline \multirow{3}{*}{$\begin{array}{l}\text { 想定 } \\
\text { 建物 } \\
\text { a) }\end{array}$} & \multirow{3}{*}{$\begin{array}{l}\text { 工事 } \\
\text { 種目 }\end{array}$} & \multicolumn{7}{|c|}{ 増工費算定階数 $\mathrm{B}^{\mathrm{b})}$} & \multicolumn{4}{|c|}{ 下記Cの出現回数 } \\
\hline & & 着 & I & 時 & & 朝 & & 月） & $\mathrm{B} \sigma \mathrm{I}$ & 0.34 & Сの & $\left(C^{(1)}\right.$ \\
\hline & & 12 & 56 & 7 & 8 & 91 & & 112 & $2: 1$ & $3: 2$ & $4: 3$ & 1 \\
\hline$\sqrt{\mathrm{Na} 33}$ & 軀体 & $2^{\text {b) } 2}$ & & & 1 & 2 & 3 & 33 & $\overline{3}$ & 2 & & $\overline{2}$ \\
\hline 1500 & 外部 & & 24 & 4 & 2 & 1 & & & 2 & & 1 & 2 \\
\hline 4 階 & 内部 & & $2 \quad 3$ & 3 & 2 & 1 & & & 1 & 2 & & 2 \\
\hline$\sqrt{\mathrm{Na} 3}$ & 軀体 & 22 & & & 1 & 2 & 3 & 32 & 3 & 1 & & $\overline{3}$ \\
\hline 2000 & 外部 & & 13 & 3 & 2 & 1 & & & & 1 & & 4 \\
\hline 3 階 & 内部 & & 12 & 3 & 2 & 1 & & & & 1 & & 4 \\
\hline $\mathrm{Na} 34$ & 軀体 & 11 & & & 1 & 1 & 2 & 32 & & & & \\
\hline 3000 & 外部 & & 12 & 3 & 2 & 1 & & & & & & \\
\hline 2 階 & 内部 & & 12 & 2 & 2 & 1 & & & & & & \\
\hline
\end{tabular}

a）想定建物の№.、基潐階面積 $\left(\mathrm{m}^{2}\right)$ 、建物の階数の順

b）增工費算定期間の施工階数（増工費算定対象の施工䈯所）

c）例えばNo. 33のB=2、№. 34のB=1の場合、比はは2:1
（3）二つ目は、各想定建物の基準階面積と増工費算定階数（増工費 算定期間の施工階数）との相関関係による。例えばNo.33とNo. 34 を比較すると、基準階面積の比は $1 ： 2$ である。したがって単純化 して考えると、No.33とNo.34の増工費算定階数の比が2:1ならば、 両者の単位増工費はほぼ同じになる。しかし実際には、この増工費 算定階数の比C は、表 7 に示すように $2: 1$ を下回るケースが多く、こ のため階数等の違いにより単位増工費に相違が生じたものである。

\section{5 増工費率と建築工事発注時期の平準化}

冬期施工において、増工費または増工費率*1の大小は、最も関心 の持たれるものの一つである。ここでは建築工事単価“2 を設定し、 増工費率がどの程度になるかを検討する。また増工費率の観点か ら、建築工事発注時期の年間平準化について概観する。

*1 増工費率＝（全増工費／建築工事費） $\times 100 （ \%)$

*2 建築工事単価 $=$ 建築工事費 $/$ 延べ床面積 $\left(\right.$ 円 $\left./ \mathrm{m}^{2}\right)$

\section{1 建築工事単価の設定}

最近の北海道の営繬工事関係の資料 2 ) から、建築工事単価を建物 の規模（延べ床面積）ごとに、図10に示すように設定する。この図 において縦の点線は、各想定建物の延べ床面積の中間を区分したも のである（例えば、想定建物No.1とNo.2の延べ床面積の中間区分 点は600 $\mathrm{m}^{2}$ と $2,000 \mathrm{~m}^{2}$ の中間の $\left.1,300 \mathrm{~m}^{2}\right)$ 。

\section{2 增工費率}

4つの想定建物について、年平均と増工費が最大となる着工時期 の增工費率を表 8 に示す。
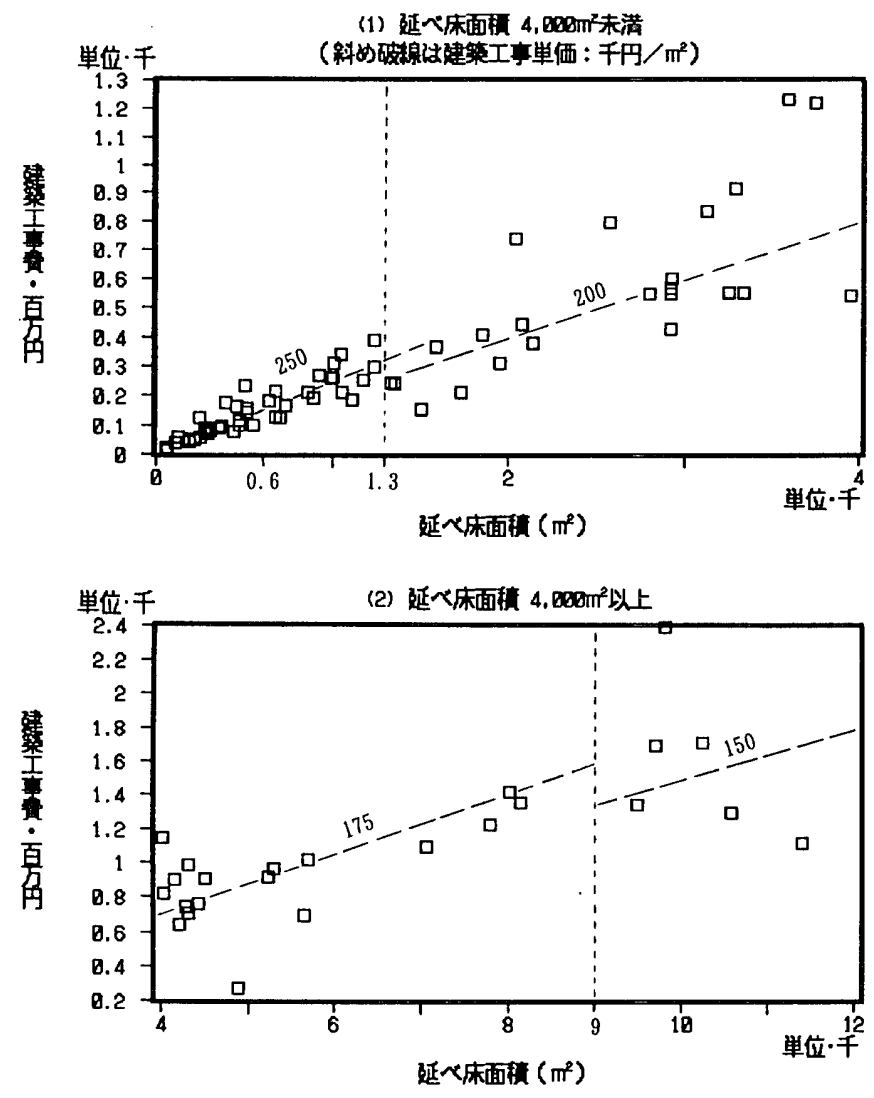

図 10 延べ床面積と建築工事費に基づく建築工事単価の設定 (「営繥年報」 2)の鉄筋コンクリート造の92例による) 
（1）年平均の増工費率は $3 \%$ 前後である。想定建物別ではNo.2が最 も大きく $3 \%$ を超え、No.3が最も小さく $3 \%$ を切っている。建設地 別では、大きい順から旭川、札幌、釧路、室蘭となっている。

（2）増工費が最大となる着工時期の増工費率は 4 ～7\%で、建物の規 模が小さいほど增工費率は大きい。 4.2 の建物規模別の単位增工費 の項で記したように、建物規模が小さいほど、着工時期別で最大と なる単位増工費が突出するためである。

\section{3 建築工事発注時期の平準化と增工費率}

現在、夏期（4月～10月）に集中している建築工事全体の発注 時期が、年間に平準化された場合の増工費率について、鉄筋コンク リート造に限定して検討する。

各規模の建物の年間建設数が異なるため、仮に図10に基づいて、 表 9 のような建設数の重みを考慮する。これに基づいて算出した結 果は表10に示すとおりで、年間全体の増工費率は、全建設地とも約 3 \%となっている。これは增工費の観点からは、工事発注時期の平 準化を可能とするために、建築工事単価を約 $3 \%$ 増しすることが必 要となることを意味する。

表 8 各想定建物の設定建築工事単価と增工異率

\begin{tabular}{|c|c|c|c|c|c|c|c|c|c|}
\hline \multirow{2}{*}{$\begin{array}{l}\text { 想定 } \\
\text { 建物 }\end{array}$} & \multirow{2}{*}{$\begin{array}{l}\text { 設定建 } \\
\text { 筑工暿 } \\
\text { 単価 } \\
(千 円 / \\
\mathrm{m}^{3} \text { ) a) }\end{array}$} & \multicolumn{4}{|c|}{ 年平均增工費率 $(\%)^{b)}$} & \multicolumn{4}{|c|}{ 最大増工費率 $(\%)^{c 1}$} \\
\hline & & 札㰾 & 旭川 & 釧路 & 室䕡 & 札邹 & 旭川 & 釧路 & 室藏 \\
\hline$\overline{1}$ & 250 & 3.07 & 3.07 & 2.99 & 2.95 & 7.37 & 7.37 & 7.27 & $\overline{7.08}$ \\
\hline 102 & 200 & 3.25 & 3.31 & 3.20 & 3. 12 & 6.82 & 6.97 & 6.76 & 6.55 \\
\hline $\operatorname{la} 3$ & 175 & 2. 85 & 2. 89 & 2.83 & 2.75 & 5.16 & 5.24 & 5.12 & 4.99 \\
\hline 04 & 150 & 2. 95 & 2.98 & 2.92 & 2. 86 & 4.52 & 4. 57 & 4. 47 & 4. 38 \\
\hline
\end{tabular}

a）図10に基づき、想定建物（建物規模）ごとに設定

b) (年平均単位增工費／設定建築工事単価） $\times 100$

c）（着工時期別の最大単位增工贅／設定建築工品単価） $\times 100$ 例えば、N Na1の場合は着工時期が12月の単位增工費

表 9 各規模の建物の建設数と重み係效

\begin{tabular}{|c|c|c|c|c|}
\hline 想定 & 建物の規模 & 適用䉇囲 & 建設数 & 建設数 \\
\hline 建物 & $\begin{array}{c}\text { 延へ床面樻 } \\
\left(\mathrm{m}^{2}\right)\end{array}$ & $\begin{array}{c}\text { 延べ床面㘔 } \\
\left(\mathrm{m}^{2}\right)\end{array}$ & a) & 重み係数b) \\
\hline VI 1 & 600 & $\sim<1,300$ & $\overline{44}$ & 0.478 \\
\hline $\mathrm{N} 0.2$ & 2,000 & $\geqq 1,300 \sim<4,000$ & 24 & 0.261 \\
\hline $\mathrm{Na} 3$ & 6,000 & $\geqq 4,000 \sim<9,000$ & 18 & 0.196 \\
\hline Na 4 & 12,000 & $\geqq 9,000 \sim$ & 6 & 0.065 \\
\hline 合計 & & & 92 & 1 \\
\hline
\end{tabular}

a)「営繥年報」2) 鉄筋コンクリート造抽出、図10参照

b) 建設数重み係效=各规模の建設数／建設数の合計

表 10 年間全体の增工費率

(各規模の建設数の重み係效を考虑した場合、表 9 参照)

\begin{tabular}{|c|c|c|c|}
\hline 建設地 & $\begin{array}{l}\text { 総增工蟫a) } \\
\text { A(千円) }\end{array}$ & $\begin{array}{l}\text { 総建築工專異 } \\
\text { B(百万円) }\end{array}$ & $\begin{array}{l}\text { 年間全体の增工費率 } \\
C=(A / B) \times 100(\%)\end{array}$ \\
\hline 札塂 & 14,902 & 498,900 & 2.99 \\
\hline 旭川 & 15,101 & 498,900 & 3.03 \\
\hline 釧路 & 14,720 & 498,900 & 2.95 \\
\hline 室蘭 & 14,374 & 498,900 & 2.88 \\
\hline
\end{tabular}

a)総增工攵 $A=\sum($ 各延べ床面積 $\times$ 各年平均単位增工費 $\times$ 各重み係数 $)$

b) 総建築工事費 $\mathrm{B}=\Sigma($ 各延べ床面積 $\times$ 建築工事単価 $\times$ 各重み係数 $)$
6. まとめと今後の課題

(1)まとめ

本報告では鉄筋コンクリート造の想定建物の増工費について、 工事条件の違いによる増工費の変動と、増工費率について、以下 の点を明らかにした。

ア. 工事条件により増工費、または単位增工費が大きいのは、a.着 工時期が春先よりも初冬の場合、b.建物の規模がより小さい場合、 c. 建設地がより寒冷で多雪な場合、d.週休がより完全（4週 2 休よ り 4 週 6 休）な場合、e.平面形状がより細長い場合、f.階数がより 少ない場合（延べ床面積が同じとして）、となっている。

1. 増工費率については、a.年平均は、建物の規模や建設地等に関係 なく $3 \%$ 前後、b.着工時期別では、最大は規模の小さい建物で 12 月着工の約 $7 \%$ 、規模の大きい建物で 9 月着工の約 $4 \% 、 c$. 建築工 事の発注時期が、年間で平準化された場合の全体の増工費率は約 $3 \%$ 、となっている。

(2) 今後の課題

通年施工を推進するに当たって、欠かすことのできない增工費低 減のための今後の課題は、a.増工費を低減できる建築計画や工事計 画の条件の明確化、b.建築構法や施工法の開発、c. 最適の発注方式 の明確化、である。

[注]

增工费の構成は下に示すとおりである1。

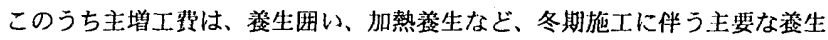
項目のための工事留からなっており、全增工費の $75 \%$ ～ $80 \%$ と大半を占めてい る。一方、副增工费は仮設建物内の暖房、敷地内の除融雪、左官工将用の水や 砂などの予熱、冬期用照明などのための工事費からなっており、項目は多い が、

全增工隦の 20 25\%を占めるに過ぎない。したがって副增工費は、一つ一つの

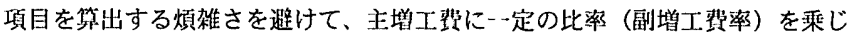
て算定するものとしている（表3）。

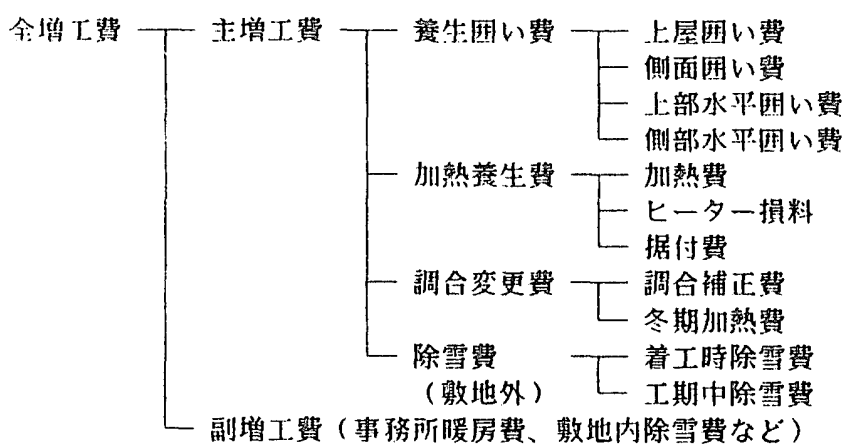

[本論文に関連する既発表論文]

[1] 中村裕史 : モデル建物による冬期施工の增工渱の算定、日本建策学会北海 道支部研究報告集、no.64, pp.23-30,1991.3

[2] 中村裕史：週休の连いによる冬期施工增工費の比较、日本建築学会北海道 支部研究報告集、no.67, pp.33-36, 1994.3

\section{[参考文献]}

1）中村裕史 : 冬期建筑工事の增工费の算定基準、日本建築学会計画系論文集、 no.491, 1997.1 (掲載予定)

2) 北海道住宅都市部営縉室 : 営繥作報 1989 $\rightarrow 1994 、 1995.3$

3）棚橋諒（編）：建筑見榡ハンドブック、朝倉書店、1966.8

4）中村裕史、ほか：北海道における建筑生渞の明日のあり方一通年施工、通 华碓用を目指して一、日本建策学会北海道支部研究報告集、no. 62, pp. 33 $-40,1989.3$

（1996年 5 月 8 日原稿受理，1996年10月30日採用決定） 